\title{
The Effect of Mulch types with Dose of N, P, and $K$ Fertilizer in Summed Dominan ratio and biomass weed Arabica (Coffea Arabica L.) Coffee in Indonesia
}

\author{
Hedi Ermarilla ${ }^{1 *}, \mathrm{Ardi}^{2}$, Dan Indra Dwipa ${ }^{3}$ \\ ${ }^{1}$ Faculty of Agriculture, Andalas University; \\ ${ }^{2,3}$ Andalas University Faculty of Agriculture \\ *email: hediermarilla234@g mail.com
}

\begin{abstract}
This research was compiled based on Factorial Randomized Group Design (RBD) consisting of 2 factors with 3 groups to obtain 36 experimental units. Each unit consists of 12 plants, 3 plants are taken as samples, so that 432 plants in total with 144 plants as samples. The first fator is the treatment of various types of mulch with 4 levels, namely $A 1=$ no mulch, $A 2=$ mulch rice husk, $A 3=$ mulch banana stem and $A 4=$ black silver plastic mulch. The second factor is the treatment of $N, P$ and $K$ anoragnik fertilizer with 3 levels, namely $B 1$ $=15 \mathrm{~g} \mathrm{~N}, 15 \mathrm{~g} \mathrm{P} 2 \mathrm{O}, 15 \mathrm{~g} \mathrm{~K} 2 \mathrm{O}, \mathrm{B} 2=20 \mathrm{~g} \mathrm{~N}, 20 \mathrm{~g} \mathrm{P} 2 \mathrm{O}$, $20 \mathrm{~g} \mathrm{~K} 2 \mathrm{O}$ and $\mathrm{B} 3=25 \mathrm{~g} \mathrm{~N}, 25 \mathrm{~g} \mathrm{P} 2 \mathrm{O} 5,25 \mathrm{~g} \mathrm{~K} 2 \mathrm{O}$. The results of the study that the treatment of various types of mulch showed the dominant weeds in the cultivation of Arabica coffee in Indonesia was Borreria alata, followed by Elausine indica and Ageratum conyzoides. While the lowest weed biomass was obtained in black silver plastic mulch or N, P and K 15g: $15 \mathrm{~g}: 15 \mathrm{~g}$.
\end{abstract}

Keywords-Weed, SDR, Biomass Weed.

\section{INTRODUCTION}

Coffee is one of the plantation commodities that has its own appeal, various processed coffee products create a taste and aroma that is attractive to fans. Coffee is also one of the mainstay commodities for export-producing estates and a source of income for farmers in Indonesia. Many factors support the cultivation of coffee plants and the development prospects for the future, but also many challenges and obstacles in the development of these commodities from various aspects. One of the obstacles is the low productivity of the coffee. The optimal productivity of coffee is caused by not using quality seeds, farming techniques that still use traditional methods, fertilization and maintenance of plants are not yet done. To overcome this problem, an action to increase the productivity of Arabica coffee is needed. In the short term, the choice of approach to increase crop productivity is intensification by fertilizing and giving mulch.

According to research conducted by Haryono (2009) that the benefits obtained when the land is given mulch is modification of soil temperature, conservation of soil moisture, reducing loss of nutrients, suppress weed growth and increase crop yields. However, low nutrient availability and availability takes a long time so mulch administration must be accompanied by fertilizer application. One of the cultivation activities is to ensure the availability of nutrients by fertilizing which is useful in supporting plant growth and production. Growth, development and continuity of good production, then the condition of the soil as a growing medium must be improved quality or ability in the supply of nutrients, both in number and type. This is the reason for the author to see the type of mulch and how many doses of N, P, K that can be able to suppress the growth of Arabica coffee weeds so that it is expected to increase productivity.

\section{MATERIALS AND METHODS}

The materials used in this study were rice straw, rice husk, banana midrib, 8 months old Arabica coffee seedlings of Sigararutang variety with plant height 10-15 $\mathrm{cm}$, Urea, SP36 and KCL fertilizer and manure. Observation of weeds after one week of treatment. Each treatment group consisted of 12 plots measuring $10 \mathrm{~m} \mathrm{x}$ $7.5 \mathrm{~m}$, the distance between plots was $0.5 \mathrm{~m}$. In the treatment plot, 12 planting holes were made with a spacing of $2.5 \mathrm{~m} \times 2.5 \mathrm{~m}$ so that there were 432 planting holes on the land. Planting holes measuring $60 \mathrm{~cm} \times 60$ $\mathrm{cm} \times 40 \mathrm{~cm}$. The next activity after making the planting hole is to apply mulch. Mulch to be used is mulch of rice husk, mulch of banana midrib and black silver mulch. Black silver plastic mulch was spread over a planting hole of $1 \mathrm{~m} 2$, while for rice husk mulch and banana midrib sprinkled with an area of $1 \mathrm{~m} 2$ leaving a hole for the 
coffee planting site Observations were made on the amount of each weed at the end of the study to observe weed biomass and SDR.

\section{RESULTS AND DISCUSSION}

\subsection{Summed Dominan Ratio (SDR) Weeds}

Table 1 shows that the three types of weeds that have the highest SDR value are Borreria alata weeds, then followed by Elausine indica and Ageratum conyzoides These three types of weeds belong to the dangerous weed species for coffee cultivation because these weeds have very fast proliferation both vegetative and generative, broad leafy type and lush canopy so that it can cover coffee plants in the early phase of growth. Another thing that can be described by the value of SDR is the level of mastery of weeds on biotic and abiotic factors that exist on the land.

According to Meilin (2006), Borreria alata is a group of broadleaf weeds that are dominant in coffee plantations or also called weed groups that need a lot of light (weeds are not shade resistant). Whereas according to Sembodo (2010) this weed has a high adaptability and is one type of broadleaf weed that disrupts the growth and yield of cultivated plants.

Borreria alata produces seeds reaching 9953 of the seeds of its perennial crops and a long level of seed dormancy (Sastroutomo, 1990). Dormancy is a reproductive weed strategy to survive in unfavorable conditions. Dormancy intensity is influenced by the environment during seed development. Dormancy in certain types causes the seeds not to germinate in the soil for years. This explains the presence of weeds in continuously cultivated agricultural land. Weed seeds in the soil have different levels of dormancy, so the germination of a population of weed seeds does not occur simultaneously. This situation causes weed seeds in the soil to remain a problem as long as the seeds are still there.

Ageratum conyzoides is a broadleaf weed with leaf formation and rapid stem lengthening. This will greatly affect the process of taking light. Competition for light is an important factor in determining the rate of plant growth. The leaves of Ageratum conyzoides are able to protect other plants and inhibit photosynthesis. According to Tjitrosoepomo et al (1987), the Asteraceae family is a broadleaf weed group that likes to be slightly moist and able to produce as many as 40,000 seeds per year.

In addition to weeds Borreria alata and Ageratum conyzoides also found weeds Crassocephalum crepidiodes. This weed habitus is in the form of upright plants, soft-wooded trunk, stem height can reach $\pm 1 \mathrm{~m}$ and have many branches. These weeds include the Asteraceae family. According to Reader and Buck (2000), weeds of the Asteraceae family can breed through seeds and have the ability to adapt to the environment and flower throughout the year. If it is associated with the type of mulch, the growth of these weeds will be hampered if you get the treatment of black silver plastic mulch.

In general, the best treatment to suppress the value of weed SDR is the use of black silver silver mulch while the value of SDR weeds will also decrease if the N: PK fertilizer dosage is lower, ie $15 \mathrm{~g}: 15 \mathrm{~g}: 15 \mathrm{~g}$. The lower the dose of fertilizer N: P: K, the lower the weed biomass. Low weed biomass at N: P fertilizer dosage: $\mathrm{K} 15 \mathrm{~g}$ : $15 \mathrm{~g}$ : $15 \mathrm{~g}$ has to do with the number of individual weeds, weed population and type of mulch. The use of black silver plastic mulch gives a decrease in the number of individual weeds. The fewer the number of individuals and the lower the number of population, the inhibition of weed growth in giving black silver plastic mulch.

Table.1: SDR value of weeds after treatment.

\begin{tabular}{|c|c|c|c|c|c|c|c|c|c|c|c|c|}
\hline \multirow{5}{*}{ Weed Type } & \multicolumn{12}{|c|}{ SDR Weed After Treatment } \\
\hline & \multirow{2}{*}{\multicolumn{3}{|c|}{$\begin{array}{l}\text { Without mulch } \\
\mathrm{N}: \mathrm{P} 2 \mathrm{O} 5: \mathrm{K} 2 \mathrm{O}\end{array}$}} & \multirow{2}{*}{\multicolumn{3}{|c|}{$\begin{array}{l}\text { Rice straw mulch } \\
\text { N:P2O5:K2O }\end{array}$}} & \multirow{2}{*}{\multicolumn{3}{|c|}{$\begin{array}{l}\text { Banana mulch } \\
\mathrm{N}: \mathrm{P} 2 \mathrm{O} 5: \mathrm{K} 2 \mathrm{O}\end{array}$}} & \multirow{2}{*}{\multicolumn{3}{|c|}{$\begin{array}{c}\text { Black silver plastic } \\
\text { mulch }\end{array}$}} \\
\hline & & & & & & & & & & & & \\
\hline & $15 \mathrm{~g}$ & $20 \mathrm{~g}$ & $25 \mathrm{~g}$ & $15 \mathrm{~g}$ & $20 \mathrm{~g}$ & $25 \mathrm{~g}$ & $15 \mathrm{~g}$ & $20 \mathrm{~g}$ & $25 \mathrm{~g}$ & $15 \mathrm{~g}$ & $20 \mathrm{~g}$ & $25 \mathrm{~g}$ \\
\hline & \multicolumn{12}{|c|}{$\%$} \\
\hline Boreria alata & 40 & 39 & 49 & 28 & 37 & 39 & 22 & 34 & 38 & 10 & 23 & 32 \\
\hline Ageratum conyzoides & 12 & 31 & 3 & 15 & 19 & 45 & 19 & 7 & 19 & 9 & 30 & \\
\hline Crassocephalum crepidiodes & 7 & & 16 & 4 & 17 & 13 & 7 & 17 & 9 & 3 & & \\
\hline Sida acuta & 3 & 5 & 20 & & & 9 & & 9 & & 6 & 5 & 31 \\
\hline Elausine indica & 13 & 14 & & 8 & 6 & & 24 & & 9 & 4 & & \\
\hline Imperata cilindrica & 10 & 4 & 3 & & 5 & & 10 & 10 & & 13 & 4 & \\
\hline Axonopus compresus & & 6 & & 5 & 12 & 8 & & & & & 8 & \\
\hline Bidens pilosa & 3 & 4 & & & & 6 & 5 & 5 & 14 & & & \\
\hline
\end{tabular}




\begin{tabular}{|c|c|c|c|c|c|c|c|c|c|c|c|}
\hline Mikania micrantha & 5 & 4 & 3 & 6 & & & 6 & & 7 & 3 & \\
\hline Brachiaria reptans & & & & & & & & & & & 33 \\
\hline Blumea lacera & & & 6 & & & & & 11 & & 15 & \\
\hline Polygala paniculata & 7 & 4 & & & & 3 & & & & & 5 \\
\hline Leptochloa chinensia & 3 & 4 & & 4 & & & & 8 & & & \\
\hline Galinsoga parviflora cav & & 6 & & 5 & 4 & 3 & & & & & \\
\hline Mimosa Infisa & & 7 & 4 & & & & & & & & \\
\hline Casia tora & & & 3 & & & & 6 & & & & \\
\hline Centella asiatica & & 4 & & & & & & & & 3 & \\
\hline Cinodon dactylon & & & & & & & & & & 6 & \\
\hline Stachytarpheta jamaicensis & & 5 & & & & & & & & & \\
\hline Nephrolepis biserrata & & & 4 & & & & & & & & \\
\hline Cyperus rotundus & & & 3 & & & & & & & & \\
\hline Physalis angulate & & & & & & 3 & & & & & \\
\hline Thitonia diversifolia & & & & & & & 1 & & & & \\
\hline
\end{tabular}

\subsection{Biomass Weed}

Based on the results of statistical analysis of coffee plants aged 8 Weeks After Plan (WAP) through a 5\% F test showed that various types of mulch and $\mathrm{N}$ : P: K fertilizer dosages affect weed biomass, while the interaction of various types of mulch and fertilizer dosage N: P: K gives effect not real to weed biomass.

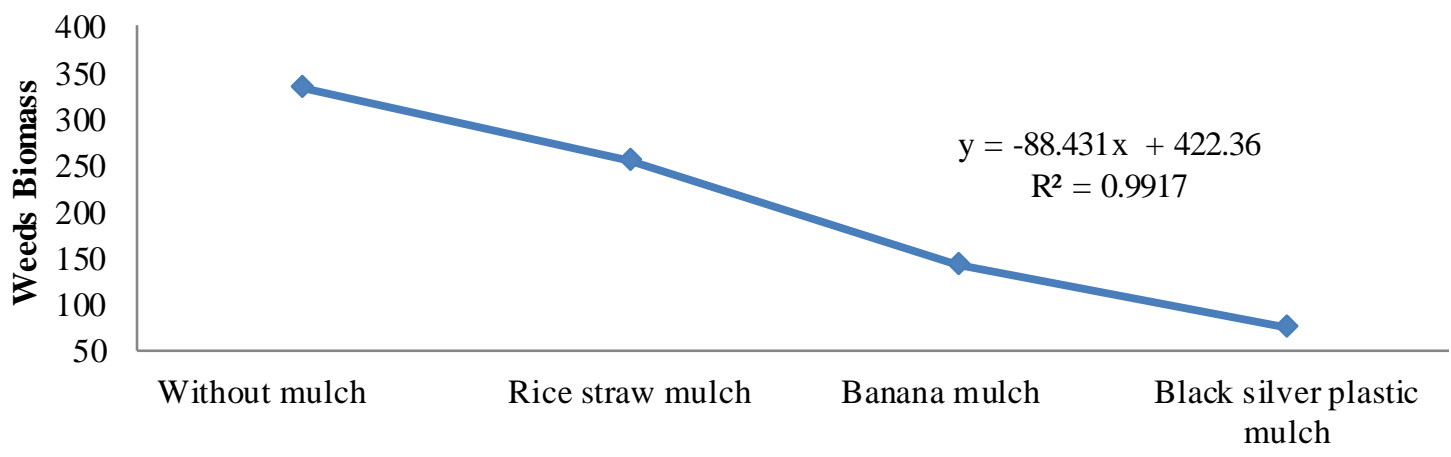

Mulch type

Fig.1: Relationship between Types of Mulch to Weed Biomass in the Age of Coffee Plants 8 WAP

Figure 1 shows the type of mulch increase weed biomass with the equation $y=-88.43 x+422.3$. The treatment that gave the highest effect for decreasing weed biomass in the treatment of black and silver plastic mulch was the value of weed biomass of $75 \mathrm{~g} / \mathrm{m} 3$. The administration of banana stem mulch and rice straw mulch gives weed biomass values of $143 \mathrm{~g} / \mathrm{m} 3$ and $255 \mathrm{~g} / \mathrm{m} 3$. While the treatment which gave the lowest effect on the decrease in weed biomass in the treatment without giving mulch was the highest weed biomass value of $332 \mathrm{~g} / \mathrm{m} 3$.

This is due to the use of various types of mulch which can suppress weed growth compared to the use of mulch. The use of black silver plastic mulch has a high influence compared to other types of mulch because black silver plastic mulch can regulate sunlight that reaches the ground surface. In general, all sunlight that hits the surface of black silver plastic, then some of the light will be reflected back into the air, in small amounts absorbed by plastic mulch and continued to reach the surface of the ground covered in black silver plastic mulch. The light reflected by the black silver mulch surface into the atmosphere will affect the top of the plant while the light that is passed down the surface of the black silver plastic will affect the physical, biological and chemical conditions of the covered phosphorus.

Sunlight is continued to melt the surface of the mulch trapped on the surface of the soil it is covering and forms a 'greenhouse effect' on a small scale, reinforced by statements (Wagoner, 1960; Tanner, 1974; Mahrer et al., 1979) in Fahrurrozi (2009) This trapped heat will increase soil surface temperature, modify groundwater balance, soil carbon dioxide, suppress weed growth, and increase 
the activity of microorganisms. Dark plastic mulch is very effective in controlling weeds (Fahrurrozi and Steward, 1994). This happens because weed seeds under black silver plastic mulch do not have access to sunlight to photosynthesize so that weeds that grow will experience etiolation and grow weak

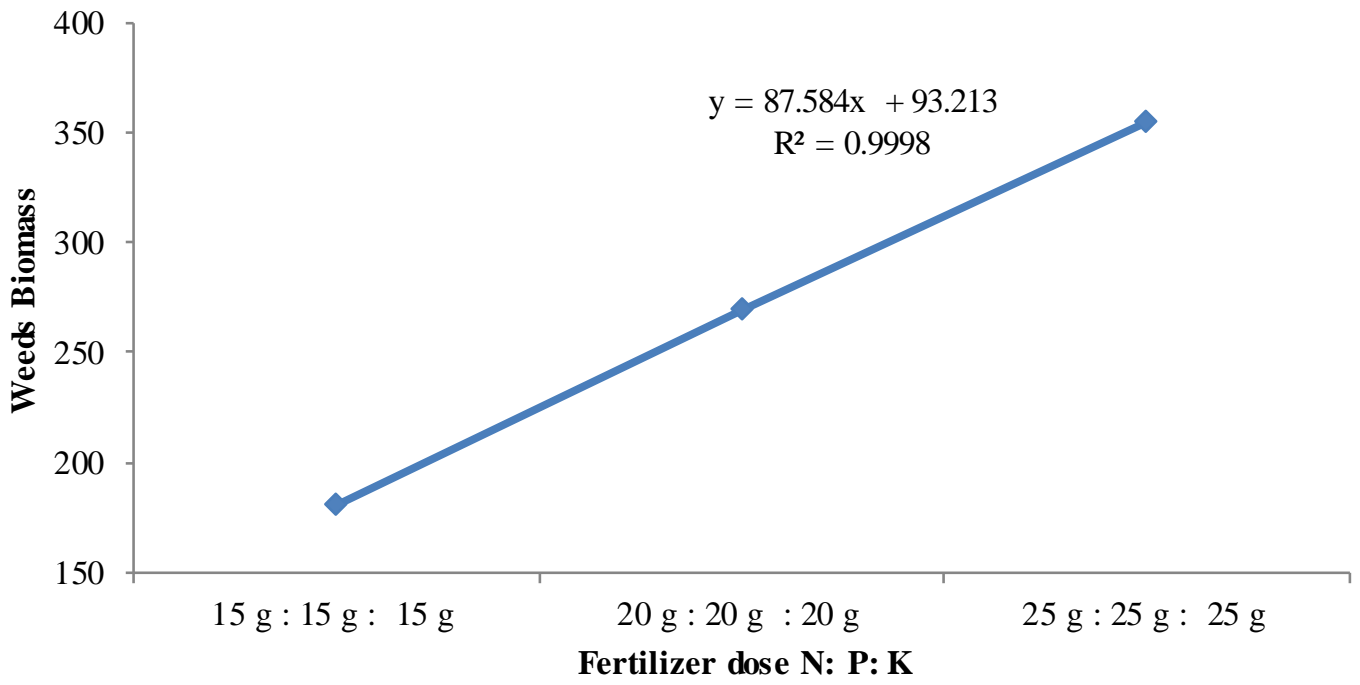

Fig.2: Relationship of N: P: K Doses to Weed Biomass in Coffee Crop Ages 8 WAP

Figure 2 shows the dosage of fertilizer $\mathrm{N}: \mathrm{P}: \mathrm{K}$ can increase weed biomass with the equation $\mathrm{y}=87.38 \mathrm{x}+$ 93.21. The treatment that gave the highest influence for the reduction of weed biomass in the treatment of $\mathrm{N}: \mathrm{P}: \mathrm{K}$ 15g: 15g: $15 \mathrm{~g}$ fertilizer was the value of weed biomass of $75 \mathrm{~g} / \mathrm{m} 3$. Provision of N: P fertilizer: K 20g: $20 \mathrm{~g}$ : $20 \mathrm{~g}$ provides weed biomass values of $143 \mathrm{~g} / \mathrm{m} 3$. While the treatment that has the lowest effect on decreasing weed biomass in fertilizer treatment $\mathrm{N}: \mathrm{P}: \mathrm{K} 25 \mathrm{~g}: 25 \mathrm{~g}: 25 \mathrm{~g}$ is the highest weed biomas s value $255 \mathrm{~g} / \mathrm{m} 3$.

It is assumed that the higher the dosage of $\mathrm{N}$ : P: K fertilizer given, the more nutrient content and organic matter in the soil, which will increase soil fertility. The more fertile the soil, the more optimal plant growth will be. This means that fertilization will increase the carrying capacity of the land but will not reduce the composition of plant yields or disturbance of weeds still exist and detrimental even though the soil is fertilized (Sukman \& Yakup, 2002).

Table.2: Weed Biomass in the Type of Mulch and Dosage Treatment N: P: KAge 8 WAP

\begin{tabular}{|c|c|c|c|c|}
\hline \multirow[t]{3}{*}{ Mulch type } & \multicolumn{3}{|c|}{ Fertilizer Dose N: P: KT } & \multirow{3}{*}{$\begin{array}{l}\text { Effect of } \\
\text { Mulch } \\
\text { Type }\end{array}$} \\
\hline & $15 \mathrm{~g}: 15 \mathrm{~g}$ & $20 \mathrm{~g}: 20 \mathrm{~g}$ & $25 \mathrm{~g}: 25 \mathrm{~g}$ & \\
\hline & $: 15 \mathrm{~g}$ & $: 20 \mathrm{~g}$ & $: 25 \mathrm{~g}$ & \\
\hline Without mulch & 84.45 & 117.57 & 130.16 & $110.73 \mathrm{~A}$ \\
\hline Rice Mulch Rice & 46.76 & 81.38 & 126.99 & $85.04 \mathrm{~A}$ \\
\hline Banana Mulch & 32.13 & 42.45 & 68.49 & $47.69 \mathrm{~B}$ \\
\hline Black Silver Plastic Mulch & 16.66 & 28.56 & 29.54 & $24.92 \mathrm{~B}$ \\
\hline \multirow[t]{2}{*}{ Effect of Fertilizer Dosage } & 45.00 & 67.49 & 88.79 & \\
\hline & $\mathrm{b}$ & $a b$ & a & \\
\hline
\end{tabular}

The numbers followed by the same large letter in the same column and the numbers followed by the same
Table 2 also shows the N: P fertilizer treatment: K 25g: 25g: 25g (88.79 g / m3) significantly different weed biomass values with fertilizer treatment $\mathrm{N}: \mathrm{P}: \mathrm{K} 15 \mathrm{~g}$ : $15 \mathrm{~g}$ : $15 \mathrm{~g}(45 \mathrm{~g} / \mathrm{m} 3)$ but different not significant with fertilizer treatment N: P: K 20g: 20g: 20g (67.49 g / m3). While the value of weed biomass was not significantly different between fertilizer $\mathrm{N}$ : P: K 20g: $20 \mathrm{~g}: 20 \mathrm{~g}$ with fertilizer dosage N: P: K 15g: $15 \mathrm{~g}: 15 \mathrm{~g}$ and $25 \mathrm{~g}: 25 \mathrm{~g}: 25 \mathrm{~g}$. This is presumably due to the increase in nutrients given by a high N: P: K fertilizer dose which will cause an increase in the number of weeds. According to Harjadi (1993), at a higher level even though symptoms of deficiency do not appear, plants will respond to fertilization with increasing yield. With the availability of nutrients that are complete with the amount of each nutrient according to the needs of the plant will be able to stimulate the growth and development of the vegetative part of the plant. small letter on the same line show different effects that are not significant according to the DNMRT level of 5\%. 
IV. CONCLUSION

Based on the experiments that have been done, some conclusions are obtained, namely

1. The dominant weed in the cultivation of Arabica coffee in Indonesia is Borreria alata, followed by Elausine indica and Ageratum conyzoides.

2. The lowest weed biomass is obtained in black silver plastic mulch or N, P and K 15g: 15g: $15 \mathrm{~g}$.

\section{REFERENCES}

[1] Fahrurrozi and K.A. Stewart. 1994. Effects of mulch optical properties on weed growth and development. Hort Science 29 (6):545

[2] Fahrurrozi, 2009. Scientific Facts Behind the Use of Black Silver Plastic Mulch https://www.researchgate.net/publication/298861359 _Scientific_Facts_B ehind_the_Use_of_Blacksilvered_Plastic_Mulches_i n_Vegetable_ProductionDiakses pada 18 Oktober 2018

[3] Harjadi, S. S. 1993. Introduction to Agronomy: PT Gramedia

[4] Reader dan Buck, 2000. Weed Growth in Environmental Conditions. PT. Gramedia Pres. Jakarta 